\title{
Nature and distribution of the deformation front in the Luzon Arc-Chinese continental margin collision zone at Taiwan
}

\author{
Ho-Shing Yu \\ Institute of Oceanography, National Taiwan University,Taipei, Taiwan (E-mail: yuhs@ntu.edu.tw)
}

Received 11 August 2003; accepted 20 April 2004

Key words: deformation front, distribution, nature, seismics, Taiwan

\begin{abstract}
Marine seismic reflection profiles from offshore SW Taiwan combined with onland geological data are used to investigate the distribution and nature of the deformation front west of Taiwan. Locations of the frontal structure west of Taiwan are generally connected in a linear fashion, although the alignment of frontal structures is offset by strike-slip faults. The deformation front begins from the northern Manila Trench near $21^{\circ} \mathrm{N}$ and continues northward along the course of the Penghu Submarine Canyon in a nearly N-S direction north of $21^{\circ} \mathrm{N}$ until it reaches the upper reaches of Penghu Canyon at about $22^{\circ} 15^{\prime} \mathrm{N}$. The deformation front then changes direction sharply to the northeast. It connects to the Chungchou thrust fault or the Tainan anticline in the coastal plain and continues northwards along the outer Western Foothills to the northern coast of Taiwan near $25^{\circ} \mathrm{N}$. Characteristics of structural style, strain regime, sedimentation and tectonics vary along the trend of the deformation front. Ramp anticlines, diapiric intrusion and incipient thrust faults are commonly associated with the deformation front. Variations in structural style along strike can be related to different stages of oblique collision in Taiwan. The deformation front (collision front) west of Taiwan can be considered as a boundary between contraction in the Taiwan orogen and extension west of the collision zone. The deformation front east of the Tainan Basin and its northward extension along the outer limit of the Western Foothills is the surface trace separating the foreland thrust belt from the nearby foredeep, not a boundary between the Chinese and Taiwan margins. The submarine deformation front off SW Taiwan is the surface trace separating the submerged Taiwan orogenic wedge from the Chinese passive continental margin, not a surface trace of the plate boundary between the Eurasian and Philippine Sea plates.
\end{abstract}

\section{Introduction}

The island of Taiwan was formed by oblique collision between the Luzon Arc and the Chinese continental margin in late Cenozoic time (Suppe, 1981; Ho, 1988; Biq, 1997). Taiwan is situated on the plate boundary separating the Eurasian plate to the west from the Philippine Sea plate to the east (Figure 1). The surface trace of the active plate boundary between the Eurasian and Philippine Sea plates was proposed by Bowin et al. (1978) to follow the tectonic front of the Manila Trench continuing northward and connecting with frontal thrust faults in western Taiwan (Figure 1). The former part of the northern Manila Trench is now buried beneath the western Taiwan foredeep and the frontal thrust of a series of westward imbricate thrusts west of the Central Range. The surface extension of the Manila Trench into western Taiwan is considered to be the western limit of major thrusts in western Tai- wan rather than the location of the subduction zone. The westernmost limit of thrust faults in western Taiwan is defined as the tectonic front or deformation front, although the exact location remains uncertain (Ho, 1982). However, the frontal thrust of the west-verging fold-and-thrust belt in western Taiwan is generally considered as the outer limit of the Western Foothills (Ho, 1988).

Reed et al. (1992) have mapped structures in the slope region off southwest Taiwan. They found west-verging ramp anticlines mainly in the lower slope and determined locations of the westernmost contractional structures (deformation front) off southwest Taiwan. The submarine deformation front extends southwards along the edge of the lower slope and gradually merges into the Manila Trench in a NNW-SSE direction but turns to a NNE-SSW direction north of $22^{\circ} \mathrm{N}$ towards Taiwan (Figure 2). However, interpretation of NNW-SSE trending structures of the submarine deformation front connected to NNE- 


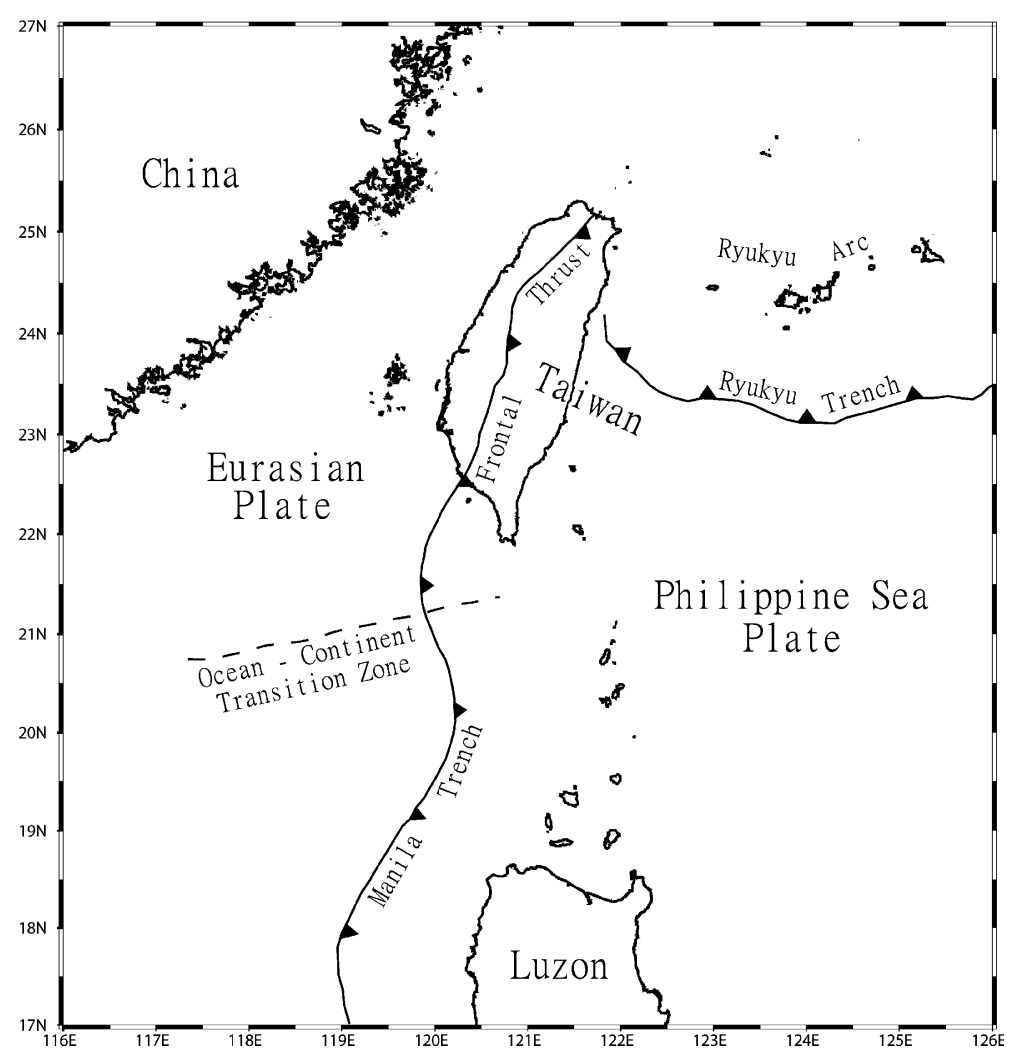

Figure 1. The surface trace of active plate boundary between the Eurasian and Philippine Sea plate in the Luzon-Taiwan region is considered as the tectonic front of the Manila Trench continuing northward into the frontal thrust faults in the western Taiwan. Modified from Bowin et al. (1978) and Liu et al. (1992).

SSW trending folds and thrusts of the Coastal Plain and Western Foothills remains controversial (Lee et al., 1992, 1995, Liu et al., 1997).

Due to southward migration of the Luzon Arc-Chinese continental margin collision in Taiwan region through time (Suppe, 1984), four stages of collision processes of the Taiwan orogen from south to north can be determined (Lallemand and Tsien, 1997): incipient collision south of Taiwan, active collision in south-central Taiwan, past collision in northern Taiwan and extension after collision offshore northeastern Taiwan (Figure 2). The location and characteristics of the collisional deformation front west of Taiwan are closely controlled by oblique collision in Taiwan ( $\mathrm{Lu}$ and Malavieille, 1994; Liu et al., 1997). In addition, $\mathrm{Lu}$ et al. (1998) pointed out that the geometry of the deformation front of the foreland thrust wedge is strongly influenced by the Peikang basement highs on the Chinese margin. Offshore SW Taiwan, the nature of the deformation front is affected by the growth of the accretionary wedge, geometry of the Chinese margin basement and tectonic evolution of the arc-continent processes (Liu et al., 1997).

From 1995 to 1999 geo-scientists from Taiwan and France jointly developed an international program of investigating the "Active Collision in Taiwan" and some results were summarized in subsequent publications (Lallemand and Tsien, 1997; Lallemand et al., 2001). The location of the deformation front is better defined and its geological and geophysical meanings are fully discussed, although controversial issues still exist. In particular, linkage between geometry, kinematics and tectonic processes of the deformation front distributed in coastal plain and offshore areas in SW Taiwan deserves further study.

The present paper is concerned with the location and nature of the deformation front along strike of the Taiwan collision zone by combining geological data from onshore and offshore areas 


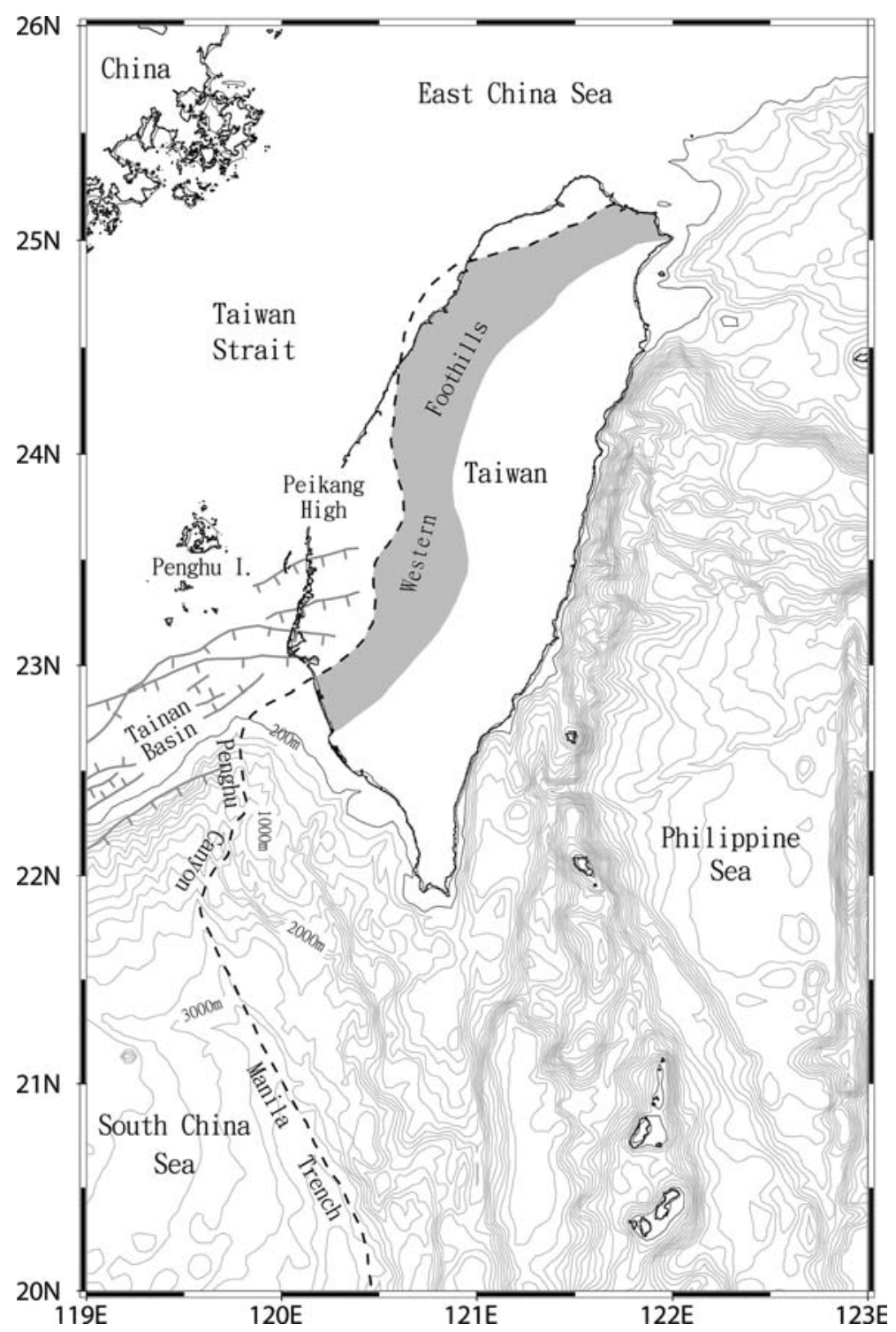

Figure 2. The deformation front begins from the northern Manila Trench near $21^{\circ} \mathrm{N}$ and continues northward along the course of the Penghu Submarine Canyon in a nearly N-S direction north of $21^{\circ} \mathrm{N}$ until it reaches around $22^{\circ} 40^{\prime} \mathrm{N}$ at the upper reaches of Penghu Canyon. The deformation front then bends sharply to the NE and connects to the Chungchou thrust fault or the Tainan anticline and continues northwards along the outer Western Foothills to the northern coast of Taiwan near $25^{\circ} \mathrm{N}$. The deformation front is marked by dashed line.

in southwestern Taiwan. Along-strike variations of structural style, strain regime, sedimentation and tectonics related to the deformation front are discussed. Emphases are placed on the characteristics of the submarine deformation front in the SW Taiwan where it exhibits a progressive northward transition from subduction, incipient collision, and active collision.

\section{Study areas and data}

The study areas include the frontal Western Foothills, Coastal Plain in western Taiwan and the shelf-slope areas of offshore SW Taiwan. Off southwestern Taiwan the sea floor is characterized by a very narrow shelf, around $10 \mathrm{~km}$ wide, and a relatively broad Kaoping Slope which 
extends to a water depth of about $3200 \mathrm{~m}$ in the northernmost South China Sea (Figure 3). The juxtaposed South China Sea Slope is west of the Kaoping Slope and extends northwestward and merges into the South China Sea Shelf of the Chinese continental margin. The SW Taiwan and Chinese margins converge obliquely northward and form a triangle-shaped depocenter south of the Taiwan Strait Shelf, that opens and deepens to the south. The physiographic boundary of these two margins is the Penghu Canyon that begins immediately below the shelf break of the Taiwan Strait Shelf and extends southwards and gradually merges into the Manila Trench (Yu and Chang, 2002).

This paper is based mainly on twenty four-channel seismic reflection profiles that mostly trend E-W across the Penghu Canyon (Figure 3). Related data in the Western Foothills and Coastal Plain are derived from published literature. Three short marine seismic surveys were carried out from 2000 to 2003 in the offshore region of southwest Taiwan to map locations of the deformation front. Seismic lines are distributed in the southernmost Taiwan Strait Shelf extending southwards to the northern

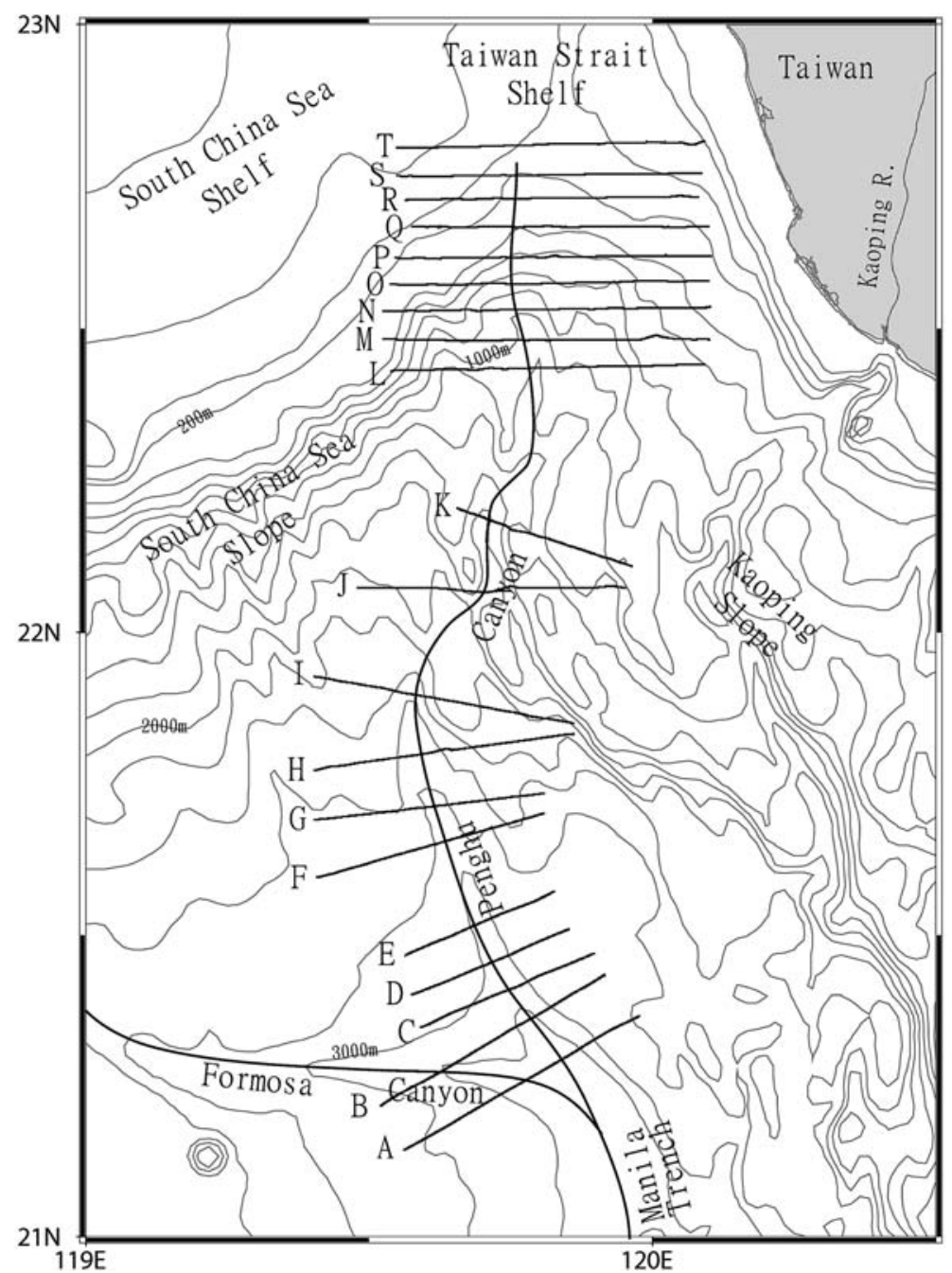

Figure 3. The study areas in the offshore SW Taiwan are characterized by a very narrow shelf, around $10 \mathrm{~km}$ wide, and a relatively broad Kaoping Slope which extends to a water depth of about $3200 \mathrm{~m}$ in the northernmost South China Sea. Twenty four-channel seismic reflection profiles labeled A-T mostly trending E-W and across the Penghu Canyon, a physiographic boundary between the Chinese and Taiwan margins, are collected. 
termination of the Manila Trench (Figure 3). An air-gun array was deployed as energy source. The DFS-V floating gain digital system was the recording device for the reflection seismic signals. Seismic reflection data were processed using the SIOSEIS system and PROMAX software at the Institute of Oceanography, National Taiwan University.

\section{Distribution of deformation front}

\section{Submarine deformation front}

Our seismic data indicate that the Chinese margin west of the Penghu Canyon is characterized by parallel and continuous seismic reflections but disturbed seismic reflections with contractional structures are prevalent in the Taiwan active margin east of Penghu Canyon. In the northern Manila Trench and lower reaches of the Penghu Canyon area (profile A on Figure 4), across the confluence of the Formosa and Penghu Canyons and the Manila Trench, the contrasting characteristics and structural styles of the Chinese passive margin and the Taiwan active margin are juxtaposed. The South China Sea Slope sediments of the Chinese margin are characterized by parallel and continuous reflections that dip east. The uppermost strata are disturbed by slumping or sliding. In contrast, the Kaoping Slope sediments derived from the Taiwan orogen are deformed into west-verging ramp anticlines immediately east of the confluence. The ramp anticline located at the most frontal part of the deformed Kaoping Slope sediments is interpreted as the deformation front (Figure 4). Seismic reflection patterns and structural styles of the Chinese and Taiwan margins observed on seismic profile B (Figure 4) are similar to those shown on profile A. Profile B shows that the deformation front is the westernmost contractional structure (ramp anticline) of the deformed Kaoping Slope sediments immediately east of Penghu Canyon. The deformation front recognized on profiles $\mathrm{A}$ and $\mathrm{B}$ can be correlated to those of the adjacent profiles $\mathrm{C}, \mathrm{D}$ and $\mathrm{E}$ and extends to the deformation front (ramp anticline) farther north at about $22^{\circ} 20^{\prime} \mathrm{N}$ that was defined by Liu et al. (1997).

Seismic profiles $\mathrm{F}-\mathrm{K}$ extend across the Penghu Canyon at around $22^{\circ} \mathrm{N}$ and reveal that

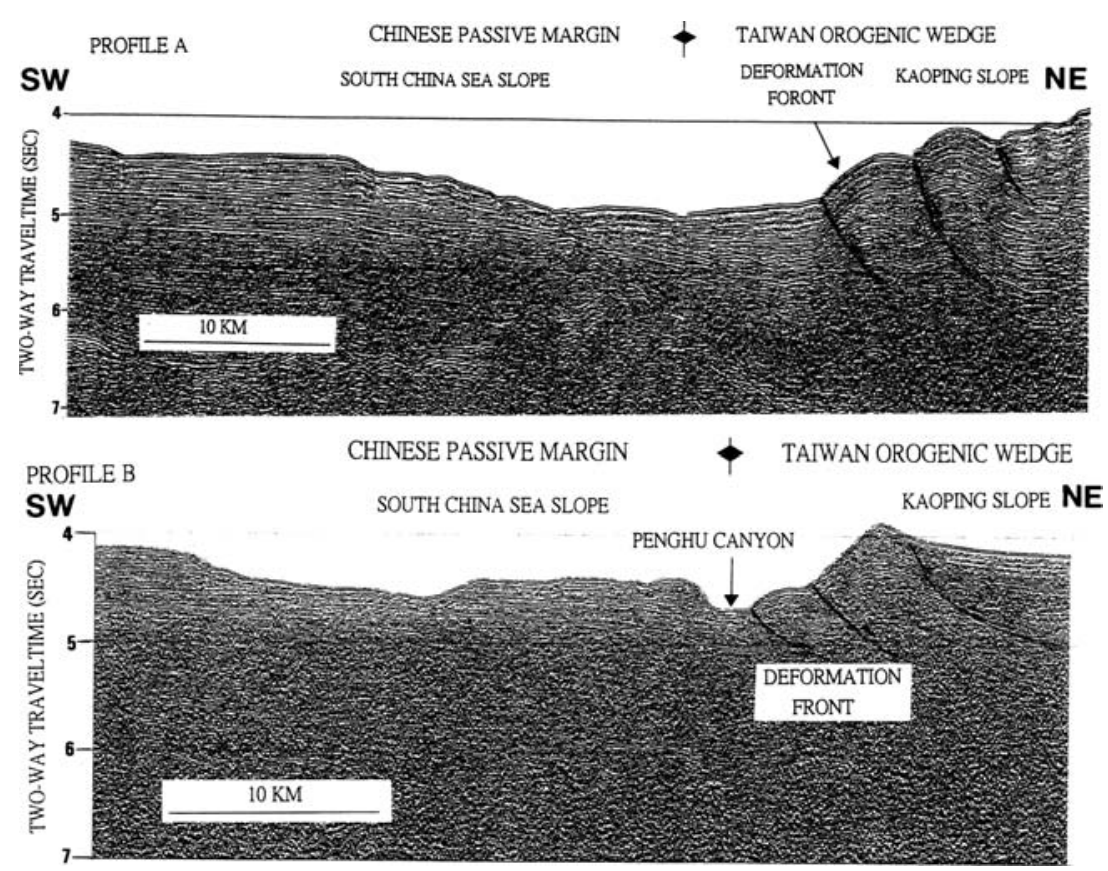

Figure 4. Profiles A and B both show that the sediments of the Chinese margin are characterized by parallel and continuous reflections that dip eastward. The frontal parts of the submerged Taiwan orogenic wedge are deformed into west-verging ramp anticlines. The westernmost ramp anticline is considered as the deformation front. Locations of profiles A and B are referred to Figure 3. 

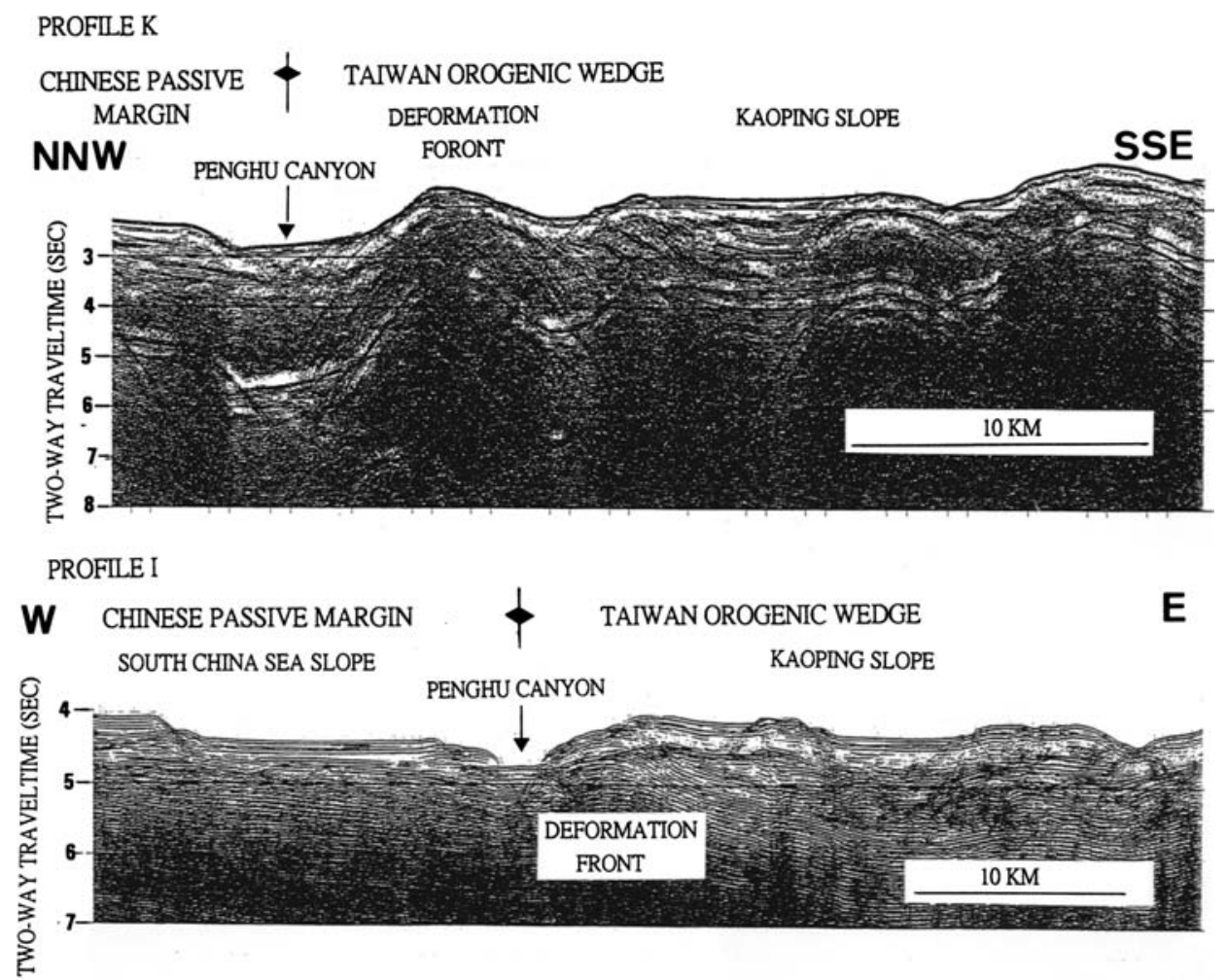

Figure 5. Profiles I and K both indicate that west of the Penghu Canyon seismic facies of the East China Sea Slope sediments are parallel and continuous reflections disturbed by slumping or sliding. The Kaoping Slope sediments east of the Penghu Canyon are deformed into west-verging ramp anticlines. The ramp anticline immediately east of the Penghu Canyon is considered as the deformation front. Location of profiles I and $\mathrm{K}$ are referred to Figure 3.

the Chinese margin strata are characterized by continuous and parallel reflections with reflections offset by slumping or sliding but Kaoping Slope sediments are deformed into westward propagating ramp anticlines. Profile I (Figure 5) shows parallel and continuous reflections of the Chinese margin west of Penghu Canyon. The strata in the upper parts of the Chinese margin are disturbed by slumping or sliding. East of Penghu Canyon, Kaoping Slope strata are deformed into ramp anticlines. The ramp anticline on the eastern side of Penghu Canyon is considered as the deformation front. Seismic facies and structures on profile $\mathrm{K}$ (Figure 5) are similar to those shown on profile I. The western frontal ramp anticline is interpreted as the deformation front. The deformation front forms a prominent bathymetric high along the eastern wall of Penghu Canyon.

Seismic profiles $\mathrm{L}-\mathrm{S}$ across both the SW Taiwan and Chinese margins in the upper slope region show that deformation fronts of the
Kaoping Slope sediments are mostly located around Penghu Canyon. Seismic profile M (Figure 6) indicates that structures of the deformed Kaoping Slope strata are characterized by diapirc intrusions that penetrate upward and rise above the sea floor to form relatively large bathymetric ridges east of the Penghu Canyon. West of Penghu Canyon a buried anticline is formed at the toe of the South China Sea Slope. The deformation front is located around Penghu Canyon, the physiographic boundary between the Chinese and Taiwan margins. Farther north, Kaoping Slope strata are characterized by reflection-free or chaotic seismic facies with highly irregular sea floor topography as shown on profiles $\mathrm{N}-\mathrm{S}$, probably resulting from rapid deposition of finegrained sediments by down-slope mass movements and erosion of the sea floor. Contractional structures such as folds, thrust faults and diapiric intrusions are hardly recognized. The deformation front can be defined as a place where seismic 


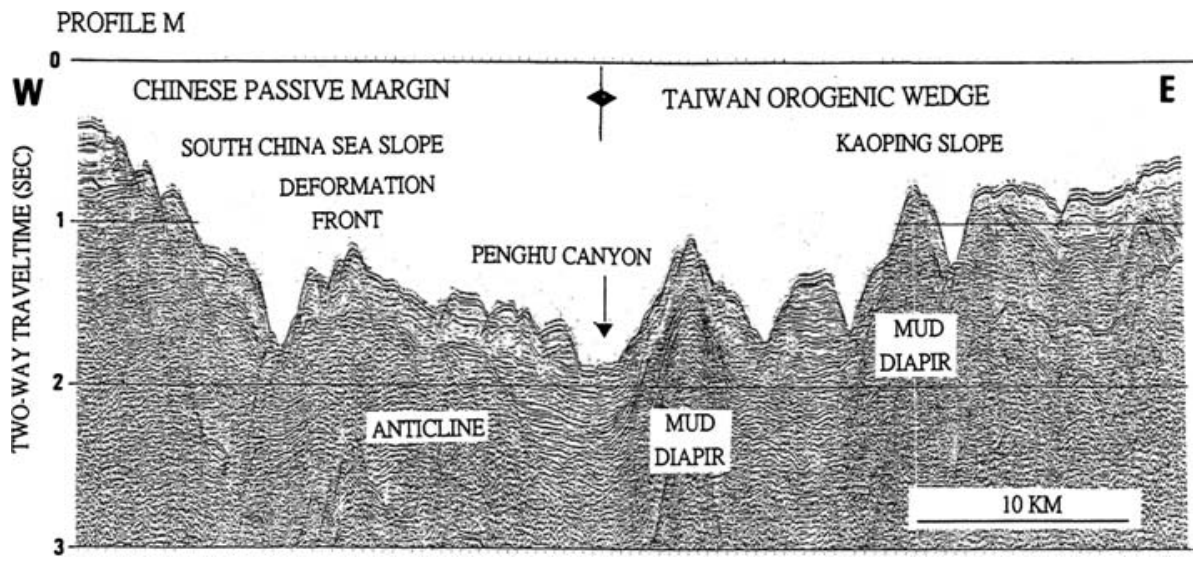

Figure 6. Profile M indicates that sediments derived from the Taiwan orogen are deposited in the Kaoping Slope and are syndepositionally deformed by diapiric intrusions, slumping and sea floor erosion. The frontal part of the deformed sediments located at the toe of the South China Sea Slope west of the Penghu Canyon is considered as the deformation front. Note that sediments from the Taiwan orogen onlap the Chinese margin westward. The location of profile $\mathrm{M}$ is referred to Figure 3.

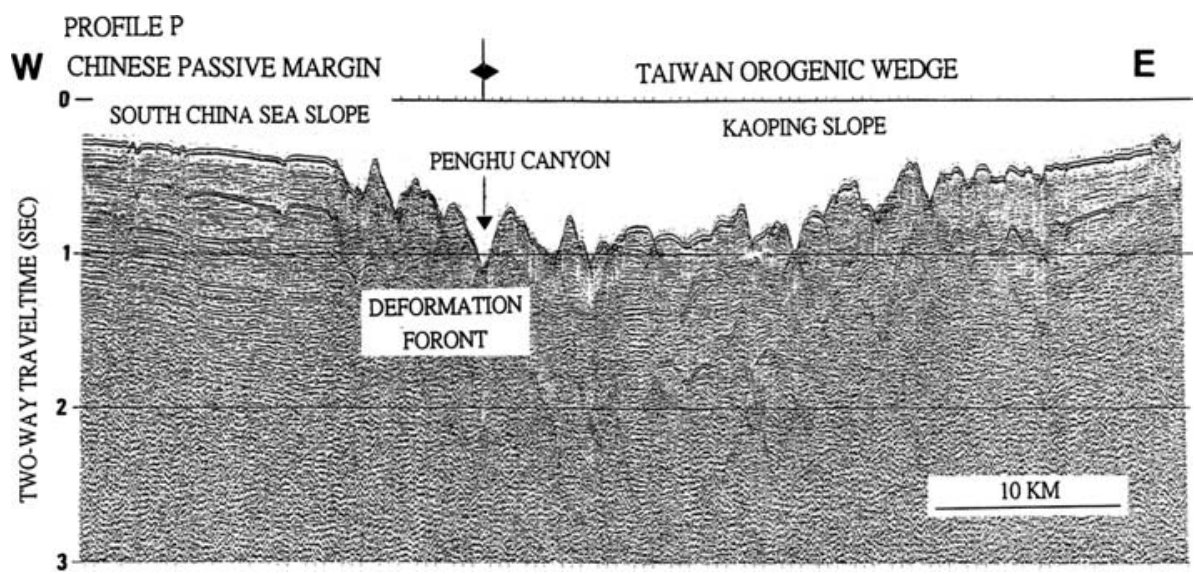

Figure 7. Profile $\mathrm{P}$ shows that the Kaoping Slope sediments are characterized by chaotic or reflection-free seismic facies with irregular sea floor. In contrast, the Chinese margin strata show seismic patterns of parallel and continuous reflections. The deformation front is considered to be at the seismic facies transition where is located west of the Penghu Canyon. The location of profile P is referred to Figure 3.

facies transition from chaotic, discontinuous reflections of the disturbed and deformed strata of the Taiwan margin to the parallel and continuous reflections of the Chinese margin strata. Liu et al. (1997) used seismic facies change as an indicator to determine the location of the deformation front beneath thick sediments under the shelf off Tainan and Kaohsiung, SW Taiwan. Seismic profile P (Figure 7) shows two contrasting seismic facies: parallel and continuous reflections dipping eastwards on the Chinese margin but chaotic and highly disturbed facies on the Taiwan side. The deformation front can be determined at the seismic facies transition west of the
Penghu Canyon. Seismic facies on the adjacent profile Q to the north are similar to those shown on profile P. The deformation front defined by the seismic facies change is located immediately east of Penghu Canyon (Figure 7) and follows closely the boundary separating the Chinese passive margin from the tectonic active Taiwan margin. This facies boundary is coincided to an inferred strike-slip fault along the southern edge of the Tainan Basin and is considered to be the deformation front by Lacombe et al. (2001). It is suggested that seismic facies change may be used to define the deformation front where structural features are not positively recognized. 

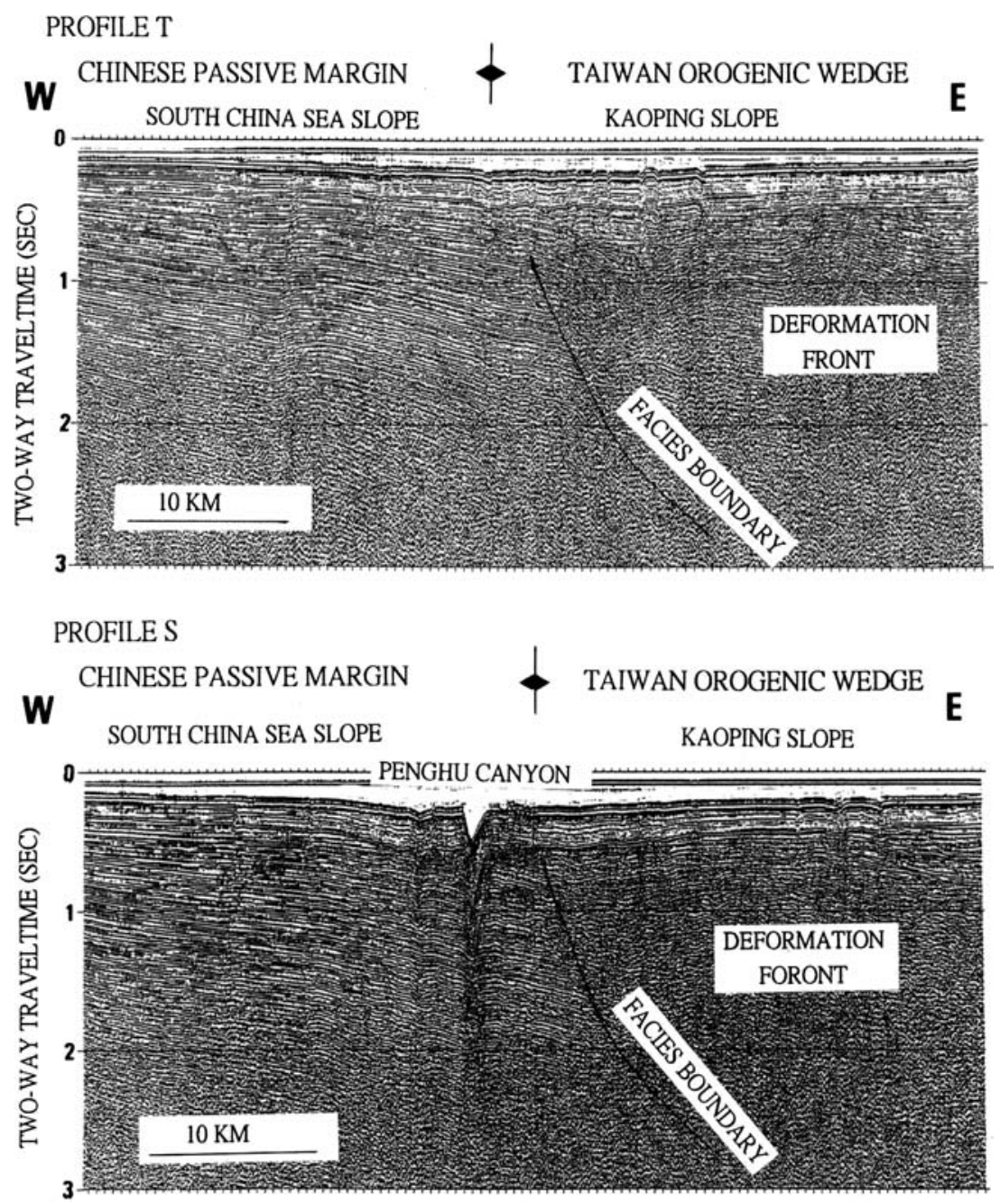

Figure 8. Profile $\mathrm{T}$ shows that the Chinese margin strata exhibit parallel, continuous and divergent reflections slightly dipping eastward, a typical passive margin shelf seismic facies but the Taiwan margin strata are characterized by discontinuous and hummocky seismic reflections. The facies transition from disturbed strata of SW Taiwan to the undeformed sedimentary sequences of the Chinese margin can be delineated and marked by a tilted upwards dashed line on the profile T. East of the facies boundary some strata of the SW Taiwan are deformed into relatively gentle anticlines of which the westernmost one is considered as the deformation front. Seismic profile $\mathrm{S}$ immediately south of the profile $\mathrm{T}$ has seismic characteristics similar to that of the profile $\mathrm{T}$, except for the presence of the V-shaped Penghu Canyon on the sea floor. The gentle anticline east of the seismic facies boundary is considered as the deformation front. Locations of profiles S and T are referred to Figure 3.

Across the southernmost Taiwan Strait Shelf seismic profile $\mathrm{T}$ (Figure 8) shows that the Chinese margin strata exhibit parallel, continuous and divergent reflections that dip slightly eastward, a typical passive margin shelf seismic facies but the Taiwan margin strata are characterized by discontinuous and hummocky seismic reflections. The facies transition from disturbed strata of SW Taiwan to the undeformed sedimentary sequences of the Chinese margin is marked by the dashed line on profile T. East of the facies boundary, some strata of SW Taiwan are deformed into relatively gentle anticlines of which the westernmost is considered to be the deformation front (Figure 8). Seismic profile $\mathrm{S}$ has seismic facies characteristics similar to profile $\mathrm{T}$, except for the presence of the V-shaped Penghu Canyon on the sea floor. The gentle anticline east of seismic facies boundary is interpreted as the deformation front (Figure 8). 
Examination of these 20 seismic profiles indicates that the submarine deformation front off SW Taiwan is distributed closely along the Penghu Submarine Canyon in a nearly N-S direction.

\section{Sea-land connection of the deformation front}

Our seismic surveys do not cover the shelf areas off Tainan-Kaohsiung, SW Taiwan. Therefore, correlation of the deformation front of offshore SW Taiwan to that in the Coastal Plain in SW Taiwan relies on previous studies. Sediments in the Coastal Plain along the Tainan and Kaohsiung areas are deformed into a series of westvergent imbricated thrusts and folds (Lee et al., 1999; Mouthereau et al., 2001). East of Tainan, two west-verging thrust faults have formed during Pleistocene to Recent time with decreasing age from east to west. The Meilin thrust fault has formed about $0.8 \mathrm{Ma}$ and the Chungchou thrust fault to the west has formed in Recent time. Lee et al. (1992) suggested that the submarine deformation front along the toe of the Kaoping Slope bends to a NE direction at $22^{\circ} 15^{\prime} \mathrm{N}$ and follows a direction of N55 E and then connects to thrust faults onshore near Kaohsiung (Figure 9). Lee et al. (1995) and Gong et al. (1995) proposed that the frontal structure of the submarine deformation front can be connected to the Meilin Fault north of Kaohsiung. Chen and Yang (1996) suggested that the submarine deformation front is located near Kaohsiung or even farther to the south (Figure 9). However, Huang (1993) and Liu et al. (1997) suggested that the submarine deformation front lies farther west of that proposed by Lee et al. (1995) and probably can be connected to the Chungchou thrust fault (Figure 9). Deffontaines et al. (1997) suggested the Tainan anticline farther northwest of Kaohsiung is the deformation front correlative to the submarine deformation front (Figure 9). The oblique collision with the Peikang basement high of the Chinese margin has resulted in a large right-lateral transfer zone along its southern edge (Lu et al., 1998). Lacombe et al. (2001) suggested that this lateral motion occurs farther southwest and connects onshore frontal folds and thrusts to the offshore deformation front. Alternatively, the structures near Kaohsiung can be correlated to the $\mathrm{N}-\mathrm{S}$ trending submarine structures farther east of the Penghu Canyon in order to distinguish them from the deformation immediately east of Penghu Canyon (Figure 9). Judging from the spatial distributions of structures onshore and offshore of the Tainan and Kaohsiung areas (Liu et al., 1997, Figure 3; Lacombe et al., 2001, Figure 6; Mouthereau et al., 2001, Figure 10), this paper suggests that the deformation front offshore SW Taiwan extends into the Chungchou thrust fault in the Tainan area.

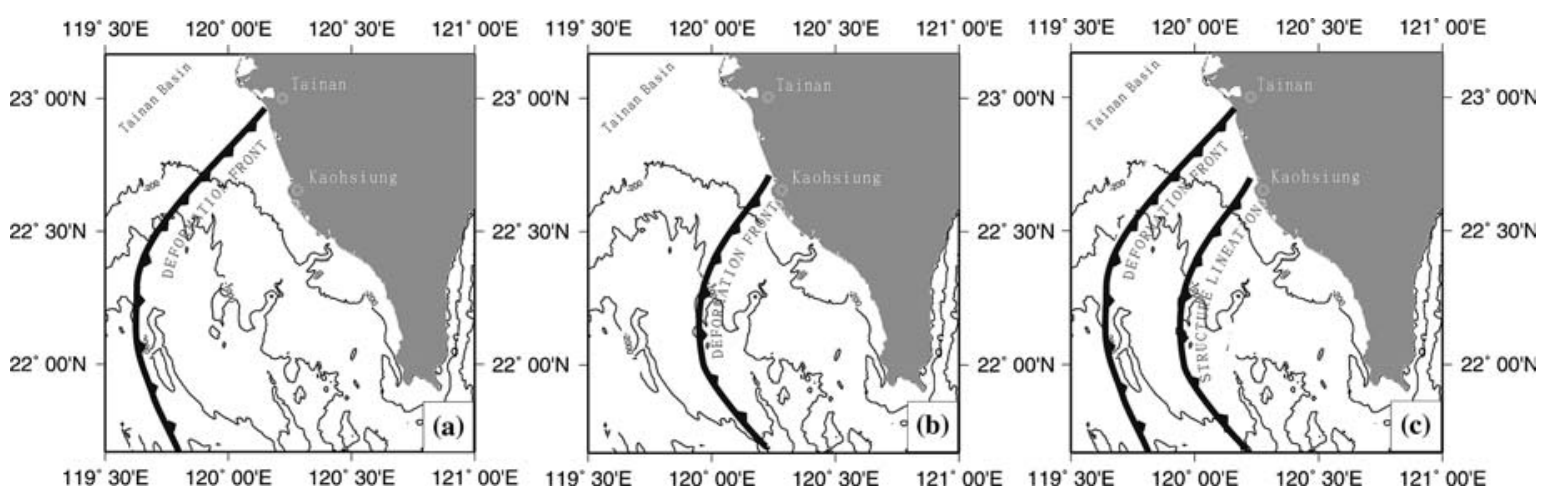

Figure 9. Schematic diagram showing three possible ways of sea-land connection of the deformation front in southwest Taiwan. The submarine deformation front along the toe of the Kaoping Slope can be continued into the Chungchou thrust fault near Tainan (a) as proposed by Liu et al. (1997). Lee et al. (1995) proposed that the frontal structure of submarine deformation front can be connected to the Meilin fault north of Kaohsiung (b). Lacombe et al. (1997) and Lacombe et al. (2001) suggested that structures near Kaohsiung can be connected to the $\mathrm{N}-\mathrm{S}$ trending submarine structures farther east of the Penghu Canyon in order to distinguish from the deformation front immediately east of the Penghu Canyon (c). 


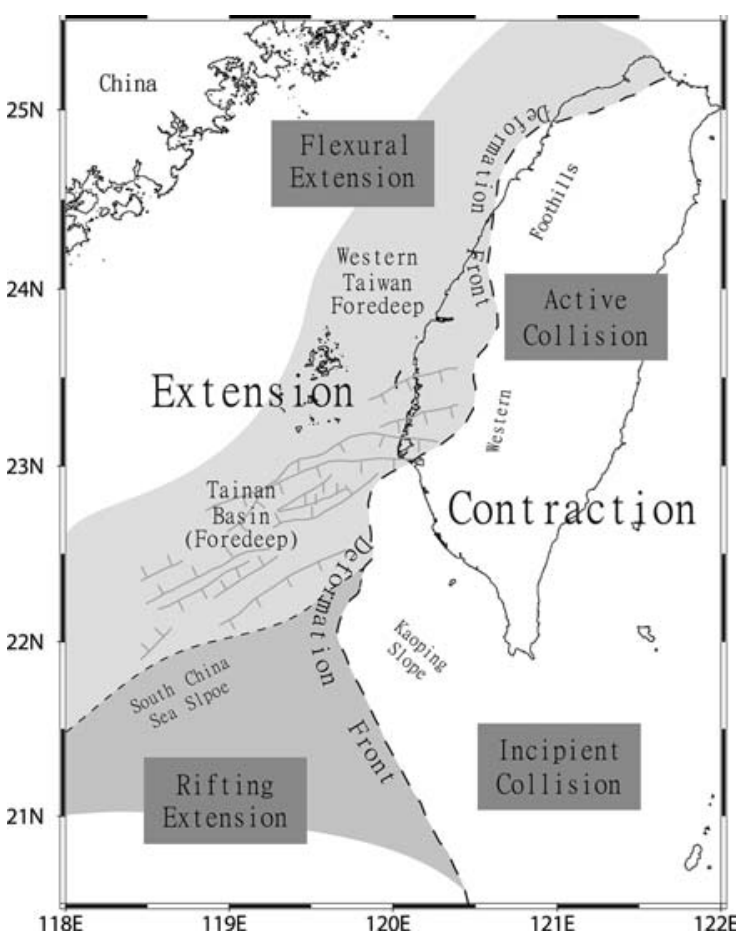

Figure 10. The deformation front (collision front) west of Taiwan can be considered as a boundary between different strain regimes, separating contraction in the Taiwan orogen from extension west of the collision zone. Extension can be further divided into flexural extension and rifting extension. The former occurs in the Western Taiwan foredeep and Taiwan Basin in response to active collision in the Taiwan orogen. The latter is present in the Chinese passive margin south of the Tainan Basin associated with incipient collision.

\section{Deformation front west of the western foothills}

On land, the deformation front generally follows the front of the Western Foothills in a curvilinear manner (Figure 2). Lu et al. (1998) suggested that contraction against the Peikang basement high is the main cause for the curvature of the thrust front. However, Deffontaines et al. (1997) pointed out noticeable lateral displacements of the deformation front caused by left-lateral motion across the NNE-SSW trending folds and thrusts along the western limits of the Western Foothills. The alignment of deformation fronts distributed between Miaoli and Kaohsiung is not continuous and is offset by four major transfer fault zones which trend $\mathrm{N} 140^{\circ} \mathrm{E}$. From north to south, these are the Sanyi, Chiayi, Chishan and Fengshan transfer fault zones. For example, the trace of the thrust front in the Western Foothills stretches out the semicircular Peikang basement high and changes its trend to a curve from convex to the WSW direction.

However, Chou and $\mathrm{Yu}$ (2002) pointed out that the coastal plain and nearby coastal zone of the Taiwan Strait off Hsinchu-Maoli-Chiai areas are zones of tectonic inversion. Submarine inverted high-angle reverse faults of Pleistocene age occur along the strike of the Taiwan orogen. These contractional structures are part of the deformation front of the foreland fold-and-thrust belt and are blind faults in the early stage of genesis of the orogenic wedge (DeCelles and Giles, 1996). The western limit of contractional structures of the foreland fold-and-thrust belt in western Taiwan forms the deformation front at the present time.

It is concluded that locations of the frontal structure west of Taiwan are generally connected into a continuous line, although the frontal structures are offset by strike-slip faults. The deformation front begins from the northern Manila Trench near $21^{\circ} \mathrm{N}$ and continues northward along the course of the Penghu Submarine Canyon in a nearly $\mathrm{N}-\mathrm{S}$ direction north of $21^{\circ} \mathrm{N}$ until around $22^{\circ} 40^{\prime} \mathrm{N}$ in the upper reaches of Penghu Canyon. The deformation front then bends sharply to the $\mathrm{NE}$ and connects to the Chungchou anticline or the Tainan anticline and continues northwards along the outer Western Foothills to the northern coast of Taiwan near $25^{\circ} \mathrm{N}$ (Figure 2).

\section{Nature of deformation front}

\section{Sedimentation and tectonics}

The topographic setting of the deformation front west of Taiwan changes progressively along strike from south to north: from deep-sea trench, to submarine canyon, shelf-slope, coastal plain, and foothills, exhibiting a transition from deep marine to subaerial settings. Morphological variations are parallel to changes in tectonic processes: subduction occurs in the Manila Trench, incipient collision in the Penghu Canyon and shelf-slope region offshore Taiwan, and active collision in the Coastal Plain and Western Foothills in south-central Taiwan. The morphotectonic significance of the deformation front is discussed as follows. 
Pelagic sediments on South China Sea oceanic crust, which is subducting beneath the Luzon Arc, are off-scraped and accreted to the inner slope of the Manila Trench. The accreted materials are then deformed in folds and thrusts. The youngest folds or thrusts on the Manila Trench slope define the deformation front (Hayes and Lewis, 1984). In other words, the formation of the deformation front associated with the Manila Trench south of $21 \mathrm{~N}$ is genetically related to the subduction process.

North of the Manila Trench, subduction is replaced by incipient collision between the Chinese margin and the Luzon Arc and a submerged orogenic wedge has formed south of Taiwan by overthrusting of the Chinese continental margin. Orogenic sediments derived from the Taiwan orogen are transported to the deep marine basin north of the Manila Trench and syn-depositionally deformed and integrated into the westward advancing orogenic wedge. Morphologically, the submerged orogenic wedge is represented as the Kaoping Slope. Structurally, the orogenic wedge is deformed into west-verging folds and thrusts. The deformation front or toe of the submerged orogenic wedge lies near the base of the Chinese margin where is bounded by the deep Penghu Submarine Canyon (Figure 4). Where continued collision has caused the submarine orogenic wedge to advance farther westward, the frontal orogenic wedge has begun to move over the toe of the Chinese margin (the South China Sea Slope) (Figure 5). Orogenic sediments supplied continuously from Taiwan are integrated into the growing orogenic wedge. More proximal to the Taiwan orogen relatively thick sediments from Taiwan are accumulated in the shelf and upper slope region off SW Taiwan. The toe of the submarine orogenic wedge is buried by thick sediments and is no longer recognized. The deformation front is represented either as the frontal contractional structure or the transition of seismic facies (Figure 7). Due to the relatively thick sediments that have accumulated on top of the submarine orogenic wedge, the shelf-upper slope region off SW Taiwan can be classified as a wedge-top depozone (DeCelles and Giles, 1996; Chiang et al., 2004).

Orogenic sediments from Taiwan transported westward onto the shelf-slope areas along the Chinese margin are terminated by the southern edge of the Tainan Basin (Liu et al., 1997). The Tainan Basin changed from a passive margin to a foreland setting during Plio-Pleistocene time (Lee et al., 1993; Chou, 1999). The facies boundary in the shelf-slope region off SW Taiwan separates the orogenic wedge of the Taiwan margin from the Tainan foreland basin of the Chinese margin is considered to be the deformation front. Several limestone hills occur in the coastal plain in the Tainan-Kaohsiung area and actually are anticlines composed of shallow-marine Pleistocene reef limestone, that was later deformed into subaerial anticlines in the transitional zone from incipient to active collision (Gong et al., 1995; Lacombe et al., 1997).

Active collision occurs in south-central Taiwan where Pliocene-Pleistocene shallow marine to terrestrial sediments derived from the Central Range of Taiwan are sequentially deformed westward into the fold-and-thrust belt. The westernmost contractional structures of the foreland fold-and-thrust belt define the location of the deformation front. For example, the foreland fold-and-thrust belt in the Taichung area consists of westward propagating thrust faults. The Shuilikeng thrust began about $2 \mathrm{Ma}$ west of the Central Range, motion of the Chelungpu thrust west of the Suilinkeng thrust occurred at about $1 \mathrm{Ma}$, and finally, the Chunghua thrust has formed since 0.5 Ma (Lee et al., 1996; Chen et al., 2000). This part of the deformation front is a surface trace separating the frontal orogenic wedge of Taiwan from the foredeep distal to the Taiwan orogen, not a boundary between the Chinese passive margin and the Taiwan active margin.

\section{Structural style}

Seismic profiles in the study area indicate that structural style of the deformation front varies along strike. In the lower Kaoping Slope north of the Manila Trench, the frontal west-vergent ramp anticline is associated with the deformation front (Figure 4). Anticlines are underlain by a thrust ramp extending westward and upward. In the upper reaches of Penghu Canyon at water depths about $1500 \mathrm{~m}$, diapiric structures on the eastern side of the Penghu Canyon become the deformation front (Figure 6). Mud diapirs associated with the deformation front are also present at the upper Kaoping Slope near Kaohsiung (Lee 
et al., 1995; Liu et al., 1997). In addition, lowangle incipient thrusts and anticline ridges located behind the thrusts form prominent undersea features at the deformation front offshore Kaohsiung (Lee et al., 1995). In general, the deformation front of the fold-and-thrust belts in western Taiwan is characterized by low-angle incipient thrusts and uplifted anticlines located immediately behind the thrust faults. For example, the Pakua anticline neighbors the eastern side of the incipient frontal thrust of Changhua fault in central Taiwan (Lee et al., 1996).

The variations of structural style along the strike of the deformation front can be related to different stages of oblique collision in Taiwan (Fuh, 1997). The lithology and thickness of orogenic sediments from Taiwan are major factors that influence the development of structures formed by collision. For example, the spacing between adjacent ramp anticlines is very small on profiles $A$ and $B$ and increases to about $8 \mathrm{~km}$ on profiles $\mathrm{H}$ and $\mathrm{J}$, due to increasing thickness of sediments (Calassou et al., 1993). The presence of mud diapirs in the offshore area of southwest Taiwan suggests that rapid deposition of thick deep-marine, fine-grained sediments creates unstable conditions under the compression, with syn-depositionally deformation into diapiric structures (Sun and Liu, 1993; Fuh, 1997). On the other hand, most coarse-grained terrestrial sediments deposited in front of uplifted hanging walls of thrust faults are later deformed into folds or thrusts in the Western Foothills. Detailed discussions of kinematics and dynamics of frontal structures are beyond the scope of this paper.

\section{Strain regime}

The deformation front (collision front) west of Taiwan can be considered as a boundary between different strain regimes, separating contraction in the Taiwan orogen and extension west of the collision zone (Figure 10). Chou (1999) described the western Taiwan foredeep as extending from the frontal foreland thrustbelt to the middle Taiwan Strait. The foredeep contains a sedimentary wedge of Pliocene-Pleistocene orogenic sediments derived from the Taiwan orogen. The foredeep sediments thicken eastward with a maximum thickness of $5 \mathrm{~km}$ underneath the coastal plain.
Chou and $\mathrm{Yu}$ (2002) pointed out that the crust underlying the western Taiwan foredeep has been flexurally downwarped and deformed by lithospheric bending in Pliocene-Quaternary time, during the formation of the Taiwan orogen. Lin and Watts (2002) discussed the relationship between orogenic loading of the Taiwan on the eastern edge of the Chinese margin and the flexure of the rifted Chinese continental margin.

The Plio-Pleistocene strata of the marine foredeep north of the Peikang basement high and west of the Hsinchu-Chiai areas are cut by normal faults due to flexural bending. For example, synorogenic flexural-extension normal faults trend north and are nearly parallel to the strike of the Changhua fault. These normal faults cut the Plio-Pleistocene strata on the northern flank of the Peikang basement high (Chou and $\mathrm{Yu}$, 2002). Southwest of the Peikang basement high lies the Tainan Basin where flexural extension normal faults also cut thick Pliocene-Quaternary strata of the Tainan Basin (Lee et al., 1993; Chou, 1999). The Tainan Basin has changed from an Oligocene-Miocene rift basin to a Quaternary foreland basin. In other words, contraction dominates east of the deformation front along the western edge of the foreland fold-andthrust belts. In contrast, flexural extension prevails in the eastern Taiwan Strait and Tainan Basin west of the deformation front.

Flexural extension normal faults are not found in the Pliocene-Pleistocene sediments of the Chinese margin south of the Tainan Basin, indicating normal faults of the Chinese passive margin of rifting extension origin. The lack of flexural-extension of this part of the Chinese margin probably is due to incipient collision and insignificant orogenic loading. The incipient collision zone south of Taiwan appears to be yielding rather than flexing (Lin and Watts, 2002).

\section{Summary and conclusion}

After a quarter century of study of the arc-continent collision in Taiwan, the location determination and characterization of the surface trace of active plate boundary between the Eurasian and Philippine Sea plates proposed by Bowin et al. (1978) have much improved. Locations of the frontal structure west of Taiwan are generally 
connected into a continuous line, although the alignment of frontal structures is offset by strike-slip faults. The deformation front begins from the northern Manila Trench near $21^{\circ} \mathrm{N}$ and continues northward along the course of the Penghu Submarine Canyon in a nearly $\mathrm{N}-\mathrm{S}$ direction north of $21^{\circ} \mathrm{N}$ until it reaches around $22^{\circ} 40^{\prime} \mathrm{N}$ at the upper reaches of Penghu Canyon. The deformation front then bends sharply to the NE and connects to the Chungchou thrust fault or the Tainan anticline and continues northwards along the outer Western Foothills to the northern coast of Taiwan near $25^{\circ} \mathrm{N}$. South of $21^{\circ} \mathrm{N}$, tectonic front of the Manila accretionary prism occurs at the inner slope of the Manila Trench where subduction dominates. The Manila Trench is considered not only a convergent plate boundary but also a zone of deformation front. North of $21^{\circ} \mathrm{N}$, the Manila Trench becomes shallower and gradually merges into the nearly N-S trending Penghu Canyon where is the intersection of the South China Sea Slope to the west and the Kaoping Slope to the east on the Taiwan side. The toe of Kaoping Slope east of the Penghu Canyon is characterized by contractional structures of folds, thrusts or diapirs where is the deformation front of the submerged Taiwan orogenic wedge. The Kaoping Slope is the frontal part of the submerged Taiwan orogenic wedge, resulting from over-thrusting of the Chinese continental margin during incipient collision. West of the NNW-SSE trending submarine deformation front is the Chinese continental margin characterized by rifting-extension normal faults. The deformation front is the surface trace separating the submerged Taiwan orogenic wedge and Chinese passive continental margin, not a surface trace of plate boundary between the Eurasian and Philippine Sea plates.

The NNE-SSW trending submarine deformation front is the boundary between the Tainan Basin to the northwest and the upper Kaoping slope and coastal plain to the southeast. The Plio-Pleistocene sequences of the Tainan Basin are characterized by flexural extension normal faults but the upper Kaoping Slope sediments are deformed into contractional folds and thrusts. The orientation of the submarine deformation fronts is mainly controlled by the inherited Peikang basement high and by the strike-slip motions. Onland Taiwan, the deformation front is the frontal folds or thrusts of the foreland fold-and-thrust belt in western Taiwan. Morphologically, it is the outer limits of the Western Foothills where active collision prevails.

Contractional structures of ramp anticline, thrust fault and diapiric intrusion occur along strike of the deformation front. The variations of structural style of the deformation front are related to different stages of oblique collision of the Taiwan orogen. The deformation front (collision front) west of Taiwan can be considered as a boundary between different strain regimes, separating contraction in the Taiwan orogen and extension west of the collision zone. The foredeep in the eastern Taiwan Strait and the Tainan Basin of the Chinese margin are subjected to flexural extension. The Chinese margin south of the Tainan Basin remains within a rifting extension regime.

\section{Acknowledgements}

We would like to thank the captain, crew and technicians who helped to collect data onboard R/V Researcher I. S. K. Hsu, National Central University helped to collect seven seismic profiles during one cruise. C.Y. Lu, Department of Geology, National Taiwan University, offered valuable comments on analyses of structures. Critical reviews and constructive comments from Steve Dorobek, Texas A \& M University and T. Y. Lee, National Taiwan Normal University, have improved this paper. This research is supported by National Science Council, Taiwan, Republic of China.

\section{References}

Biq, C., 1997, Taiwan, in: Moore, E.M. and Fairbridge, R.W. (eds.), Encyclopedia of European and Asian Regional Geology. Chapman \& Hall, New York, pp. 711-717.

Bowin, C., Lu, R.S., Lee, C.S. and Schouten, H., 1978, Plate convergence and accretion in Taiwan-Luzon region, $A A P G$ Bull. 62, 1645-1672.

Calassou, S., Carrouque, C. and Malavieille, J., 1993, Genesis and evolution in transfer zones in thrust wedge: Experimental study, Tectonophysics 221, 325-344.

Chen, A.T. and Yang, Y.L., 1996, Lack of compressional overprint on the extensional structures in offshore Tainan and the tectonic implications, TAO 7, 505-522.

Chen, W.S., Erh, C.H., Chen, M.M., Yang, C.C. and Chang, I.S., 2000, The evolution of foreland basins in the western Taiwan: Evidence from the Plio-Pleistocene sequences, Bulletin Central Geol. Survey 13, 137-156. 
Chiang, C.S., Yu, H.S. and Chou, Y.W., 2004, Characteristics of the wedge-top depozone of the southern Taiwan foreland basin system, Basin Res. 16, 65-78.

Chou, Y.W., 1999, Tectonic framework, flexural uplift history and structural patterns of flexural extension in Western Taiwan Foreland Basin. National Taiwan University Ph. D. thesis, 125 p. (in Chinese).

Chou, Y.W. and Yu, H.S., 2002, Structural expression of flexural extension in the arc-continent collisional foredeep of western Taiwan, GSA Spec. Paper 358, 1-12.

DeCelles, P.G. and Giles, K.A., 1996, Foreland basin system, Basin Res. 8, 105-125.

Deffontaines, B., Lacombe, O., Angelier, J., Chu, H.T., Mouthereau, F., Lee, C.T., Deramond, J., Lee, J.F., Yu, M.S. and Liew, P.M., 1997, Quaternary transfer faulting in the Taiwan Foothills: evidence from a multisource approach, Tectonophysis 274, 61-82.

Fuh, S.C., 1997, Structural evolution of the oblique arccontinent collision onland and offshore southern Taiwan. National Taiwan University, Ph. D. thesis, 166 p. (in Chinese).

Gong, S.Y., Lee, T.Y., Wu, J.C., Wang, S.W. and Yang, Y.M., 1995, Possible links between Pliocene-Pleistocene reef development and thrust migration in the southwestern Taiwan. International Conference and 3rd Sino-French Symposium on Active Collision in Taiwan, Program and Extended Abstracts, 113-119.

Hayes, D.E. and Lewis, S.D., 1984, A geophysical study of the Manila Trench, Luzon, Philippines, I. Crustal structure, gravity, and regional tectonic evolution, J. Geophy. Res. 89, 9171-9195.

Ho, C.S., 1982, Tectonic evolution of Taiwan explanatory text of the tectonic map of Taiwan, Ministry of Economic Affairs, Republic of China, $126 \mathrm{pp}$.

Ho, C.S., 1988, An introduction to the geology of Taiwan: Explanatory text of the geological map of Taiwan, Second Edition, Ministry of Economics Affairs, Republic of China, $192 \mathrm{pp}$.

Huang, Y.L., 1993, Structural styles offshore southwestern Taiwan. Master thesis, National Taiwan University, 58 pp. (in Chinese).

Lacombe, O., Angelier, J., Chen, H.W., Deffontaines, B., Chu, H.T. and Rocher, M., 1997, Syndepositional tectonics and extension-compression relationships at the front of the Taiwan collision belt: A case study in the Pleistocene reefal limestones near Kaohsiung, SW Taiwan, Tectonophysics 274, 83-96.

Lacombe, O., Mouthereau, F., Angelier, J. and Deffontaines, B., 2001, Structural, geodetic and seismological evidence for tectonic escape in SW Taiwan, Tectonophysics 333, 323-345.

Lallemand, S.E. and Tsien, H.H., 1997, An introduction to active collision in Taiwan, Tectonophysics 274, 1-4.

Lallemand, S.E., Liu, C.S., Angelier, J. and Tsai, Y.B., 2001, Active subduction and collision in Southeast Asia, Tectonophysics 333, 1-7.

Lee, J.C., Lu, C.Y., Chu, H.T., Delcailau, B., Angelier, J. and Deffontaines, B., 1996, Active deformation and paleostress analysis in the Pakua Anticline area of western Taiwan, TAO 7, 431-446.

Lee, T.Y., Tang, C.H., Ting, J.S. and Hsu, Y.Y., 1993, Sequence stratigraphy of the Tainan Basin, offshore southwestern Taiwan. Petroleum Geol. Taiwan 28, $119-158$.

Lee, T.Y., Tang, C.H. and Hsu, Y.Y., 1992, Structural geometry of the deformation front between $22^{\circ} \mathrm{N}$ and $23^{\circ} \mathrm{N}$, offshore southwestern Taiwan arc-continent collision zone, $\operatorname{EOS~73,~} 539$ p.

Lee, T.Y., Hsu, Y.Y. and Tang, C.H., 1995, Structural geometry of the deformation front between $22^{\circ} \mathrm{N}$ and $23^{\circ} \mathrm{N}$ and migration of the Penghu Canyon, offshore southwestern Taiwan arc-continent collision zone. International Conference and 3rd Sino-French Symposium on Active Collision in Taiwan, Program and Extended Abstracts, 219-227.

Lee, Y.S., Shen, K.S., Wu, L.C., Hong, C.S., Ho, S.C., Huang, T.Y., Chen, H.W. and Chang, Y.C., 1999, Evolution of foreland basin in southwestern Taiwan. Cenozoic sedimentary basins in Taiwan Symposium, extended abstract, Taipei, Taiwan, 229-234 (in Chinese).

Lin, A.T. and Watts, A.B., 2002, Origin of the West Taiwan basin by orogenic loading and flexure of a rifted continental margin, J. Geophy. Res. 107, 1029-1048.

Liu, C.S., Liu, S.Y., Kuo, B.Y., Lundberg, N. and Reed, D.L., 1992, Characteristics of the gravity and magnetic anomalies off southern Taiwan, Acta Geol. Taiwanica 30, 123-130.

Liu, C.S., Huang, I.L. and Teng, L.S., 1997, Structural features off southwestern Taiwan, Mar. Geol. 137, 305-319.

Lu, C.Y. and Malavieille, J., 1994, Oblique convergence, indentation and rotation tectonics in the Taiwan mountain belt: Insights from experimental modeling, Earth Planet. Sci. Lett. 121, 477-494.

Lu, C.Y., Jeng, F.S., Chang, K.J. and Jian, W.T., 1998, Impact of basement high on the structure and kinematics of the western Taiwan thrust wedge: Insights from sandbox models, TAO, 9, 533-550

Mouthereau, F., Lacombe, O., Deffontaines, B., Angilier, J. and Brusset, S., 2001, Deformation history of the southwestern Taiwan foreland thrust belt: Insights from tectono-sedimentary analyses and balanced cross-section, Tectonophysics 333, 293-322.

Reed, D.L., Lundberg, N., Liu, C.S. and Kuo, B.Y., 1992 , Structural relations along the margins of the offshore Taiwan accretionary wedge: Implications for accretion and crustal kinematics, Acta Geologic Taiwaninca 30, 105-122.

Sun, S.S. and Liu, C.S., 1993, Mud diapirs and submarine channel deposits in offshore Kaohsiung-Hengchen, southwest Taiwan, Petroleum Geol. Taiwan 28, 1-14.

Suppe, J., 1981, Mechanics of mountain building and metamorphism in Taiwan, Geol. Soc. China Mem. 4, 67-89.

Suppe, J., 1984, Kinematics of arc-continent collision, flipping of subduction, and back-arc spreading near Taiwan, Geol. Soc. China Mem. 6, 21-34.

Yu, H.S. and Chang, J.F., 2002, The Penghu Submarine Canyon off southwestern Taiwan: Morphology and origin, TAO 13, 547-562. 